\title{
The Indonesian Slum Tourism: Selling the Other Side of Jakarta to the World Using Destination Marketing Activity in the Case of "Jakarta Hidden Tour"
}

\author{
Agus Pramadi $^{1}$, Indra Kusumawardhana $^{* 2}$ \\ ${ }^{1}$ An independent researcher \\ ${ }^{2}$ The permanent lecturer at Department of International Relations, Universitas Pertamina, Jakarta
}

\begin{abstract}
This research is constructed based on the reality of slum tourism as a new phenomenon in the era of globalization. The locus is selected as it is related to Jakarta Hidden Tour case in Indonesia. The question posed is how to promote slum tourism in the Jakarta Hidden Tour to the international world and raison d'être. To answer the problem formulation, the researcher uses eclectic analytical framework which are commodification theory by Karl Spracklen and destination marketing theory by Youcheng Wang and Abraham Pizam. By using qualitative method, departing from above-mentioned understanding, this paper claims that slum tourism in the case of Jakarta Hidden Tour as a form of valorization offered to the world. Whereby, the core argument is slum tourism phenomenon that arise in Indonesia is one of the dark side of Indonesia's economic development that generates inequality especially in big cities.
\end{abstract}

Keywords: Slum tourism, Commodification, Jakarta Hidden Tour

\section{Introduction}

Since the mid-1990s, a new form of tourism has occurred in the globalizing cities of several so-called developing countries or emerging nations. So far, only a few empirical studies of this specific phenomenon within the tourism industry have been conducted (Cf. Brazil: Freire-Medeiros 2007, 2009; Menezes 2007; Jaguaribe and Hetherington 2004; for South Africa: Rolfes et al. 2009; Ludvigsen 2002; Ramchander 2004, 2007; Rogerson 2003, 2004; Margraf 2006). All those research is initial references for this paper to continue the discourse on similar field of interest by focusing on Jakarta as the capital city of Indonesia. To prove the intensification of this phenomenon, whereby it is globally spread across developing countries struggling to overcome severe inequality due to rapid economic development.

\section{Methodology}

The big question on this paper attempt to tackle is how poverty could be sell internationally to attract global tourist all over the world? In what way slum tourism in the Jakarta Hidden Tour case is sold to the international world? The researcher uses the commodification theory and destination marketing by Youcheng Wang and Abraham Pizam as a conceptual fundamental.
By using qualitative method, this study conducted an in-depth analysis to prove its propositions related to the phenomenon, namely (1) that slum tourism is a form of valorization, causing the phenomenon of the rise of poverty tourism and (2) the analysis found destination marketing as its instrument appears in the way of selling poverty in the case of Jakarta Hidden Tour.

This paper claims that slum tourism in the case of Jakarta Hidden Tour as a form of valorization offered to the world. Whereby, the core argument is slum tourism phenomenon that arise in Indonesia is one of the dark side of Indonesia's economic development that generates inequality especially in big cities. Poverty turned into a commodity to be marketed as an international tourist attraction.

\section{Discussion}

"Globalization" is a very uneven process, with unequal distribution of benefits and losses [1]. The core driving variable that propel slum tourism spread across the world is because globalization of economy already intertwined many society of this world under an unequal capitalist system. The phenomenon of inequality is closely linked to poverty, social inequality, and economic equity or the distribution of prosperity in which relating to the globalization. In economic perspective, "Economic globalization constitutes

\footnotetext{
*Corresponding author: indra.kusumawardhana@universitaspertamina.ac.id.
} 
integration of national economies into the international economy through trade, direct foreign investment (by corporations and multinationals), short-term capital flows, international flows of workers and humanity generally, and flows of technology"2. Immanuel Wallerstein have seen the growing integration of the world economy in related ways as the organic extension of national capitalism" [2]. Moreover, Appadurai argues that the urban poor are increasingly able to position themselves simultaneously within local and bordercrossing networks, utilizing global, horizontal networks to achieve physical and social changes in their direct environment [3]. Because, for most of developing countries with a variety of conditions of underdevelopment are being worried that the integration of the world only benefits the developed countries. Whilst, the poor are most of the population of developing countries who are unlikely to enjoy the opportunities created and even forced to be marginalized and slumped into the poverty ravine.

The extent and spread of slums not only helps us to recognize that they are not anomalous and pathological phenomena in the urban landscape but also a manifestation of urban poverty [4]. Moreover, spread from Rio de Janeiro to Mumbai, short, organized tours of poor areas have grown in popularity. Admittedly by this paper, the development of guided tours in destinations and places of poverty and degradation is controversial, probably because the combination of pleasure and poverty affects the sensitivity and moral values of public opinion [5]. Take a promenade to visit the most disadvantaged parts of the respective city are often essential features of this form of tourism. Basically, tourism lives on what is different. Its economic implications alone urge it to constantly create new products and open new segments on the market.

Tourism always looks for new places, inventing sights and sites which are then marked and marketed as tourist attractions. The fact that tourism needs innovations for purposes of self-preservation is by no means new. What is intriguing, however, is to look beyond this pure logic of market mechanisms to understand how, why and with what implications places of tourism are socially constructed. Spracklen mentioned on his book about the meaning of tourism, in one sense, of course, tourism has always been a product of capitalism, a leisure pursuit of the modern age, industrialization and modernity. Tourism has various meanings along with modernism era [6]. Spracklen explained that the globalization and commodification of tourism is the reason for the changing meaning of tourism today. However, the view sees that the commodification of tourism is a product of capitalism, industrialization, and modernity. For Rolfes (2009) and Freire-Mediros (2009, 2013) valorization means the commodification of poverty [7].

The concept slum tourism refers to commoditizes poverty as a tourist attraction that emerged amid the dynamics of globalization and modernization. Furthermore, Rolfes (2009) and Freire-Mediros call the commodification of poverty in slum tourism as valorization [7]. The concept is mushrooming in different parts of the world. "Over the past two decades there has occurred an expansion and geographical spread of slum tourism with its establishment and growth in several destinations of the global South, including India, Philippines, Jamaica, Mexico, Egypt, Ghana, Namibia and Zimbabwe' [8]. According to Eveline Durr and Rivke Jaffe, slum tourism involves transforming poverty, squalor and violence into a tourism product. Drawing on both altruism and voyeurism, this form of tourism is a complex phenomenon that raises various questions concerning power, inequality and subjectivity [9]. From this vantage point this paper stated that under the condition of global inequality; poverty has undergone significant transformation in terms of meaning from negative and hideous phenomenon that attracted a big chunk of effort to eradicate its existence into a tourism commodity.

The pioneer of the slum tourism concept is South Africa (the township) and Brazil (the favela). It is widely accepted that the more recent form of slum tourism started in South Africa [10]. The development of the slum concept in the southern hemisphere is characterized by global poverty which is a common problem with every nation in the world. Therefore, the international community visiting the slum area brings its own agenda related to poverty: "pioneer 'slummers' is an interesting agenda related to poverty: Reformers, political activists and 'helpers', either by profession or by altruism" Koven [10]. Today many of those tours are operated and marketed by professional companies. This kind of tour is offered on a relatively large scale in South African cities like Johannesburg and Cape Town, Brazil's Rio de Janeiro, as well as in the Indian metropolises Calcutta, Mumbai and Delhi, to name some important examples [11]. Moreover, today many of those tours are operated and marketed through professional companies to attract international tourist as the primary target, rarely domestic tourist group interested in such tourism. Rolfes also mention that the number of tourists to these disadvantaged districts is increasing constantly [11]. It is estimated that 40,000 such tourists visit Rio de Janeiro each year, while in Cape Town the figure is assumed to be even higher, within a range of about 300,000 visitors.

Indonesia is one of the place that slum tourism existed, particularly in Jakarta. A tour experience held by Jakarta Hidden Tour in which showing the hidden Jakarta, the other side of Jakarta as a capital city and metropolitan city. This article examines notably slum tourism in the case of Jakarta Hidden Tour. Moreover, destination marketing concept is a tool to spread poverty issue in the context of tourism. For instance, Frenzel et. al said that, "In Jakarta, Indonesia, Ronny Poluan was the first to start commercial slum tourism [10]. After a period of unemployment, the former documentary filmmaker founded his company 'Jakarta Hidden Tours' in 2008. For a fee of US\$56 for two people, the company offers one of five different tours leading to the slums of Ciliwung, Tanah Abang, Papango, Galur or Luar Batang [12]. To our knowledge he is still the only one who offers organized slum tours in Indonesia.

In Jakarta, a tour to experience The Hidden Jakarta (Jakarta Hidden Tour) costs US\$25, this is the average 
price that provides tours to some Kampongs in several hours and includes interaction with residents. There are no private tours offered, one package is all included in one group of tourists. The interview notes informed by Ronny Poluan indicates that one group of tourists in Jakarta Hidden Tour consists of 4 people, but it can be 30 tourists per day, so that, I must recruit additional tour guides. Residents in slum Kampong are very interested, it is due to half of tour cost (50\%) goes to them, while at the same time, tourists often give helps directly to the slum dwellers, where most people live on less than \$3 a day [13]. Meanwhile, Frenzel stated that the cost to experience slum tourism in Jakarta Hidden Tour is $\$ 56$ (Approximately Rp. 800.000,00) for two persons [10].

With each visit to The Hidden Jakarta, the residents seemed happy and thankful. It is a difficult matter for most tourists that usually come from America, Australia, and European Countries. The place, as it is seen, full of dirt and improperly built, but it does more a matter of a social and cultural interaction, the way how tourists could begin to see The Hidden Jakarta as a community, not just a slum. The interaction is a good socio-cultural exchange that brings economic support, however, it does need time and process [13]. From this point this paper sees Jakarta Hidden Tour, as it named, is an activity which explores a hidden poverty story of modern city; a capital of country, it matters because in a poverty zone, a real tourism will get hard to develop, or may be, will lead a false interpretation. Because under this condition, poverty treated as a commodity to fulfill the lust of many tourist in this world. As Marx states that: "The commodity is, first of all, an external object, a thing which through its qualities satisfies human needs of whatever kind [14]. The nature of these needs, whether they arise, for example, from the stomach, or the imagination, makes no difference. Nor does it matter here how the thing satisfies man's [sic] need, whether directly as a means of subsistence, i.e. an object of consumption, or indirectly as a means of production."

So, in this case we can view poverty as a commodity. Furthermore, Butler mentioned the person who facilitates the tour as a curator [7]. Curator in the oxford learner's dictionary refers to person who in charge of a museum, art gallery, etc. Museum that are identical to study a cultural heritage, then in this context, poverty is manifested as a cultural heritage. Frenzel points out that slums have place related semantics of poverty, squalor and desperation [7]. Indeed, it is the opposite of cultural heritage. The problem has raised while poverty becoming a commodity and a cultural heritage. Bear in mind, slum tourism has been generated all over the world, particularly in the south hemisphere. Probably unsurprisingly, claims that it will spread like a virus and even becoming a culture stroll as differently the preference of tourism emerged now. Emerging of new media like internet succeed to shape our reality today. Jakarta hidden tour uses internet as a bridge to send the message of poverty to the world. The process to grow awareness about poverty in the case of Jakarta hidden tour is relating to the destination marketing concept. According to Wahab [15], Defined destination marketing as the management process through which the National Tourist Organizations and/or tourist enterprises identify their selected tourists, actual and potential, communicate with them to ascertain and influence their wishes, needs, motivations, likes and dislikes, on local, regional, national and international levels and to formulate and adapt their tourist products accordingly in view of achieving optimal tourist's satisfaction thereby fulfilling their objectives."

More than that, Jakarta Hidden Tour unveils the condition of poor metropolitan city management. As Jakarta frequently is displayed as high urban lifestyle city, the audience and part of Jakartans do not conceive what the other poor side of Jakarta. This efforts is intertwined with the Sustainable Development Goals number 11 about Sustainable Cities and Communities which aims to raise public awareness of poor environmental management. Jakarta Hidden Tour as slum tourism uplifts environmental issue in order to not remain silent.

Poverty tourism in Jakarta has its own magnetic power because Jakarta is the capital city of Indonesia so that the excess is still the main thing for foreign tourists. However, In the future will not close if this is mushroomed in various cities in Indonesia. When interpreted positively and not skeptical, then this tour can be a unique way to arouse government awareness that poor people need more help and attention. Sometimes, people tend to exercise bad preconceive so that skepticism arises and then creates a negative image. But, Jakarta hidden tour be a threat if slum tourism is a new cultural heritage that maintains poverty well. It will remain much more debate. The concept of destination marketing is related to attract community based on their wishes. As the expectations of visitors change and further specialization occurs in the leisure market, destinations will have to realign themselves with these trends and changes to provide goods and services that will create extraordinary and memorable experiences for visitors [15]. For this study, Jakarta hidden tour seeks to sell poverty with destination packaging. Prominent poor places in Jakarta like kampong luar batang (sailor kampong), kampong pulo and kampung melayu (ciliwung river kampongs), kampong bandan (the old city) is also the destinations of Jakarta hidden tour. That shows different experiences for the tourist.

\section{Conclusion}

The concept of Slum Tourism continues to grow until now. Spearheaded by South Africa and Brazil in 1991/1992 then reached Indonesia in 2008 through the Jakarta Hidden Tour phenomenon. As Terry Flew stated that new media is "good things" or "bad things" for society [16], Jakarta Hidden Tour uses the internet as a bridge to connect social messages where doing sociocultural activities are good things. Jakarta Hidden Tour is like two blades that have negative or positive effects depending on where we put the point of view to interpret the phenomenon. The negative side just like Fabian Frenzel (2013) mentioned that slum tourism with the term "valorization" is a commodification of poverty into a destination tourism object ${ }^{7}$. And today, it is another 
side of human life behind the modern society in Jakarta as the capital city of Indonesia.

\section{References}

1. J Puspitawati, Ekologi Keluarga Konsep dan Lingkungan, PT Penerbit IPB Press, Bogor (2013).

2. M. Khor, Globalization and the South: Some Critical Issues, Penang Malaysia, Third World Network (2000).

3. J. Bhagwati, In Defense of Globalization, New York, Oxford University Press, Inc (2004).

4. A. Appadurai, "Deep democracy: urban governmentality and the horizon of politics", Environment and urbanization, 13(2), 23-43 (2001).

5. S. Goswami, "The slums: a note on facts and solution", Indian Streams Research Journal, 3, 1-10 (2013).

6. B. Freire-Medeiros, "The favela and its touristic transits", Geoforum, 40(4). 580-588 (2009).

7. K. Spracklen, The Meaning and Purpose of Leisure, London, Palgrave Macmillan (2009).

8. F. Frenzel, Slum tourism in the context of the tourism and poverty (relief) debate, Die Erde, 144 (2), 117- 28 (2013).

9. M.C. Rogerson and T. Mthombeni, "From Slum
Tourism to Slum Tourists: Township Resident Mobilities in South Africa", Nordic Journal of African Studies, 24 (3\&4), 319-338 (2015).

10. E. Dürr and R. Jaffe, Theorizing Slum Tourism: Performing, Negotiating and Transforming Inequality, European Review of Latin American and Caribbean Studies, 93, 113-123 (2012).

11. F. Frenzel., K. Koens, and M. Steinbrink, Slum Tourism: Poverty, power, and ethics, New York, Routledge (2012).

12. M. Rolfes, "Poverty tourism: theoretical reflections and empirical findings regarding an extraordinary form of tourism", GeoJournal, 75(5), 421-442 (2010).

13. A. S. Febrina, "Taking a tour on the poor side", The Jakarta Post, June 9, 2009. Retrieved October 1, 2017, retrieved from http://www.thejakartapost.com in 27 August 2017 (2009).

14. R. Prasetyanti, Slum Kampong Tourism "Jakarta Hidden Tour": Designing Eco-Cultural Based ProPoor Tourism, EJIS European Journal of Interdisciplinary Studies Articles, 3 (2015).

15. K. Marx, Capital, v. 1, London, Penguin (1976).

16. Y. Wang \& A. Pizam, (Eds), Destination marketing and management: Theories and applications, Cabi (2011). 